\title{
Novel insight into tricephalic white leghorn strain of Gallus gallus chicken embryo
}

\begin{abstract}
Introduction: Polycephaly or multiple cephalic animals is one of the uncommon abnormalities; the condition of having more than one head with a shared body which needs to be fully considered.
\end{abstract}

Materials and methods: Among 3000 fertilized eggs used to examine the gonadal primordial germ cells (gPGCs) at stage 28 (6-day-old) of White Leghorn strain of Gallus gallus chicken embryo.

Results: Tricephalia and other malformations were found and the condition of the heads (including three nervous systems), the heart and other parts of the body were fully described. Each lateral head had its own complete eyes; two hearts were not completely separated from each other and the rest of the bodies were externally unique. The central head (between two heads) not completely formed the eyes and brain.

Conclusion: The findings showed various anatomical variations in chicken embryos which should be consider in poultry farms to share their data on a bigger scale.
Volume 3 Issue 2 - 2018

\author{
Farzaneh M,' Khoshnam SE ${ }^{2}$ \\ 'Department of Stem Cells and Developmental Biology, Royan \\ Institute for Stem Cell Biology and Technology, Tehran, Iran \\ ${ }^{2}$ Department of Physiology, School of Medicine, University of \\ Medical Sciences, Ahvaz, Iran
}

Correspondence: Farzaneh M, Department of Stem Cells and Developmental Biology, Cell Science Research Center, Royan Institute for Stem Cell Biology and Technology, Tehran, Iran, Tel +9891 0457 9736, Fax +98 193954644 ,

Email Maryamfarzaneh2013@yahoo.com

Received: November 19, 2016 | Published: April 25, 2018

Keywords: polycephaly, tricephalia, chicken embryo, abnormality

\section{Introduction}

Avian are a good model for in-vitro and in-ovo research. ${ }^{1-5}$ Two-headed (bicephalia) and three-headed (tricephalia) or polycephalia animals are the only type of multi-headed creatures seen in the environment. ${ }^{6,7}$ These abnormalities form by the same process that leads two or three heads joined directly to each other. Egg abnormalities and deformed chicken embryo occur with almost every breed of hen. Previous reports showed several morphological abnormalities in avian species. ${ }^{8}$ The most commonly observed twoheaded animals are shark, ${ }^{9-12}$ amphibian, ${ }^{13,14}$ snake, ${ }^{15}$ fish, ${ }^{16-19}$ pig, ${ }^{20}$ spider, ${ }^{21}$ and reptile. ${ }^{22}$ Also, recently we reported the first bicephalia in chick embryo (unpublished data). Tricephalia is an extremely rare condition in which three heads are joined directly together. The occurrence of the tricephalia (three headed) phenomenon is a remarkably rare form of prenatal deformation that has not been documented. In this case, cranial structures like eyes and the primary brain were triplicated between three heads. Also, the presence of two hearts and other individual internal organs of the body were clear from neck to tail. Anatomical deformation in chicken can be attributed to several factors such as presence of parasites within the individuals, bad nutrition or genetic abnormality and the environment during embryonic development. This paper documents the first novel insight into tricephalia in the White Leghorn strain of Gallus gallus chicken embryo.

\section{Materials and methods}

In this study, we report one case of conjoined three heads in one embryo in a 5.5 days old chicken embryo. Photographs and descriptions of this embryo was prepared in comparison to normal embryo (figures $1 \mathrm{~A}$ and B). Measurements were done from the photographs taken under a stereomicroscope. This abnormality was observed during dissecting out the gonadal PGCs (gPGCs) from chick embryos. The eggs were normally incubated once they were delivered from the Animal Sciences Research Institute of Iran, except for some times when they were kept in a refrigerator at $8{ }^{\circ} \mathrm{C}$ for two or three days before incubation. The eggs were incubated at $38^{\circ} \mathrm{C}$, humidity $67 \%-70 \%$ and rotated a 50 degree angle every 15 minutes (Figure 1).

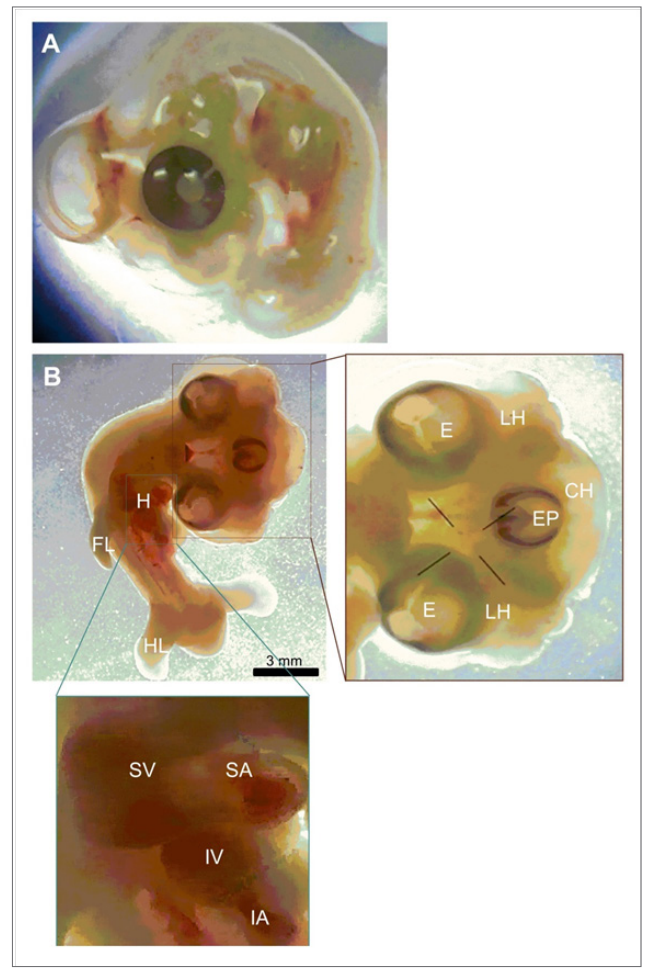

Figure I Tricephalia abnormality in 5.5 days old chicken embryo. (A) Normal chicken embryo. (B) Tricephalia chicken embryo. LH, lateral head; E, eye; EP, eye placode; $\mathrm{CH}$, central head; FL, fore-limb; $\mathrm{HL}$, hind-limb; $\mathrm{H}$, heart; SV, superior ventricle; SA, superior atrium; IV, inferior ventricle; IA, inferior atrium. 


\section{Results}

The conjoined three heads in one embryo was found among 3000 eggs which examined in a 5.5 days old chicken embryo. The craniofacial triplication was found with a completed eye for two lateral heads and early eye placode for the central head. The frequency of observed unfertilized eggs was about $0.03 \%$ of the eggs. Each lateral head had their own compartments and they had same size. Two hearts not separated from each other completely and the rate of heart beating was abnormal. The rest of the body including limbs and short tail were normal and the body size of whole embryo was abnormal

\section{Discussion}

In the malformed embryo, tricephalia (HH28), we clearly observed three discrete forebrains and midbrains, although the embryo at this stage is not transparent. Due to having only one sample, we did not investigate this stage further. In the cases presented here, the abnormalities were probably caused by disruption of developmental pathways during the gastrulation and neurulation process in the early embryo. ${ }^{23,24}$ In this study, we do not know in our case's spontaneous tricephalia (5.5 days) how the secondary and tertiary streaks have been formed to establish the new heads. Previous studies, shows that there is a possibility that doubling Hensen's node for any reason may initiate bicephalia. ${ }^{25}$ Although this number of abnormalities was too small to allow the authors to estimate the percentage of chicken abnormalities on a large scale such as in poultry farms, the percentage of abnormalities gained from each poultry farm during research could help producers to revise their environmental conditions. Studies on the early stages of chicken embryos reduce the cost of chick maintenance.

\section{Conclusion}

In our investigation at early stages of chicken development, around $10-15 \%$ of the eggs were unfertilized and about $10 \%$ of the eggs had growth retardation, as well as $2-3 \%$ had single eye with small body size in which they may not able to reach the point of hatching. There is no literature on tricephalia in avian embryos and we showed the first tricephalia abnormality in chicken embryo. In the case that we presented, the abnormality was probably caused by disruption of genetic and developmental pathways during the neurulation process in the early chicken embryo.

\section{Acknowledgements}

This study was financially supported by This study was funded by grants provided from Royan Institute and Iranian Council of Stem Cell Technology and the Iran National Science Foundation (INSF). The authors declare that there is no conflict of interest.

\section{Conflict of interest}

Authors declare that there is no conflict of interest.

\section{References}

1. Farzaneh M, Hassani SN, Mozdziak P, et al. Avian embryos and related cell lines: A convenient platform for recombinant proteins and vaccine production. Biotechnology Journal. 2017;20(5).

2. Farzaneh MS, Khoshnam P, Mozdziak. Concise Review: Avian Multipotent Stem Cells as a Novel Tool for Investigating Cell-Based Therapies. JDVAR. 2017;5(1):00125.

3. Farzaneh M, SE Khoshnam, M Nokhbatolfoghahai. First scientific record of two cases of partial twinning in the chick embryo, Gallus gallus domesticus. Veterinary Record Case Reports. 2016;4(2):e000353.

4. Farzaneh M, Attari F, Khoshnam SE, et al. The method of chicken whole embryo culture using the eggshell windowing, surrogate eggshell and ex ovo culture system. Br Poult Sci. 2018;59(2):240-244.

5. Farzaneh M, Attari F, Mozdziak PE, et al. The evolution of chicken stem cell culture methods. Br Poult Sci. 2017;58(6):681-686.

6. Basaran S, Güzel R, Keskin E, et al. Parapagus (dicephalus, tetrabrachius, dipus) conjoined twins and their rehabilitation. Turk $J$ Pediatr. 2013;55(1):99-103.

7. Cohodas M. The Bicephalic Monster.

8. Robertson GG, De Bandi H, Williamson AP, et al. Brain abnormalities in early chick embryos infected with influenza-a virus. Anat Rec. 1967;158(1):1-9.

9. Galván Magaña F, Escobar Sánchez O, Carrera Fernández. Embryonic bicephaly in the blue shark, Prionace glauca, from the Mexican Pacific Ocean. Marine Biodiversity Records; 2011.

10. Goto M, Toru Taniuchi, Naoyuki Kuga, et al. Four dicephalous specimens of the blue shark, Prionace glauca, from Japan. Japanese Journal of Ichthyology. 1981;28(2):157-165.

11. Wagner C, P Rice, A Pease. First record of dicephalia in a bull shark Carcharhinus leucas (Chondrichthyes: Carcharhinidae) foetus from the Gulf of Mexico, USA. J Fish Biol. 2013;82(4):1419-1422.

12. Muñoz Osorio LA, Mejía Falla PA, Navia AF. First record of a bicephalic embryo of small tail shark Carcharhinus porosus. J Fish Biol. 2013;82(5):1753-1757.

13. Velo Anton G. Bicephaly in Salamandra salamandra larvae. Herpetological Bulletin. 2007;101(31).

14. Fernández Álvarez FÁ, et al. Fernando Ángel, Recuero Ernesto. First record of bicephaly in Lissotriton boscai (Amphibia, Caudata, Salamandridae). Journal of Zoology. 2011;7(1):161-163.

15. Gvozdenovic S. First record of dicephalism in the four-lined snake Elaphe quatuorlineata Lacépède, 1789 (Serpentes: Colubridae) from Montenegro. Natura sloveniae. 2014;17(1):49-50.

16. Cable L. A two-headed embryo of the pipefish, Syngnathus floridae Journal of the Elisha Mitchell Scientific Society. 1940;56(1):135-139.

17. Guida L, Walker TI, Reina RD. First record of a bicephalic chondrichthyan found in Australian waters; the southern fiddler ray, Trygonorrhina dumerilii (Chondrichthyes: Rhinobatidae). Marine and Freshwater Research. 2014;65(5):396-399.

18. Delpiani S, Deli Antoni MY, Barbini SA, et al. First record of a dicephalic specimen of tope Galeorhinus galeus (Elasmobranchii: Triakidae). J Fish Biol. 2011;78(3):941-944.

19. Blanco A, P Quintas, M Planas. First observations of conjoined twins in newborn seahorses, Hippocampus guttulatus Cuvier. J Fish Dis. 2012;35(9):705-708.

20. Bishop M. The nervous system of a two-headed pig embryo. Journal of Comparative Neurology. 1921;32(4):379-428.

21. Mikulska I, L Jacunski. A two-headed monster of the spider Tegenaria atrica CL Koch. Acta Arachnologica. 1970;23(1):17-19.

22. Spadola F. G Insacco. Newborn dicephalic Podarcis sicula. Acta Herpetologica. 2009;4(1):99-101.

23. Glinka A, Wu W, Delius H, et al. Dickkopf-1 is a member of a new family of secreted proteins and functions in head induction. Nature. 1998;391(6665):357-362.

24. Nie X. Dkk1,-2, and-3 expression in mouse craniofacial development. Journal of molecular histology. 2005;36(5):367-372.

25. Cooke J, Takada S, A McMahon. Experimental control of axial pattern in the chick blastoderm by local expression of Wnt and activin: the role of HNK-1 positive cells. Dev Biol. 1994;164(2):513-527. 